\title{
Perencanaan Strategis Sistem Informasi untuk Mendukung Mutu dan Produktif ( Studi Kasus: PT. Mitrametal Perkasa )
}

\author{
Baenil Huda \\ Fakultas Teknologi dan Ilmu Komputer, Universitas Buana Perjuangan Karawang \\ baenil88@ubpkarawang.ac.id \\ Jl. H. S. Ronggowaluyo Telukjambe Timur Karawang 41361
}

\begin{abstract}
Abstrak
Saat ini kemajuan Teknologi Informasi bukan sesuatu hal yang asing bagi segala aspek kehidupan manusia. Terutama dalam bidang perusahaan yang pastinya mengharuskan penggunaan sebuah teknologi demi kelangsungan bisnis perusahaannya. Untuk itu suatu perusahaan mau tidak mau harus bersaing dalam memperbaiki proses bisnisnya, baik dalam segi sumber daya maupun strategis bisnis. Perusahaan harus melibatkan teknologi ini untuk mengolah seluruh sumber daya yang ada diperusahaan guna mendapatkan kinerja produktivitas baik dari segi pelayanan maupun hasil produksi. Adapun metodologi yang digunakan dalam penelitian ini adalah metode Ward And Peppard, yang mempunyai konsep terdiri dari tahapan masukan dan tahapan keluaran serta hasil akhir yaitu sebuah portofolio aplikasi pada masa yang akan datang
\end{abstract}

Kata Kunci : Teknologi Informasi, Metodologi, Ward And Peppard,

\section{Pendahuluan}

Dunia kerja saat ini tidak luput dari peranan teknologi terutama dalam hal pemanfaatan sistem informasi (SI). Dimana, cara manusia atau organisasi dapat mengumpulkan, memproses, menyimpan, menggunakan, dan menyebarkan informasi. Hal ini sangat jelas sekali dengan memanfaatkan sistem informasi, maka suatu organisasi akan lebih maju lagi. Namun pada kenyataannya, masih banyak organisasi yang belum memanfaatkan sistem informasi tersebut. Banyak faktor yang menyebabkan suatu organisasi belum memanfaatkan sistem informasi ini dalam organisasinya. Salah satunya yaitu karena implementasi sistem informasi tidak sesuai dengan strategi bisnisnya, atau dengan istilah lain tidak sesuai dengan kebutuhannya.

Untuk bisa dimanfaatkan dengan baik sistem informasi oleh organisasi, maka diperlukan perumusan strategi bisnis, terkait dengan visi dan misi organisasi tersebut. Dengan kata lain, bisa dinyatakan bahwa diperlukan strategi untuk implementasi sistem informasi yang tepat sesuai kebutuhan. Strategi SI akan berguna untuk mendukung strategi bisnisnya dan meningkatkan daya saingnya.

Perencanaan strategi SI perlu adanya obyek yang akan dikaji. Maka obyek yang akan ditinjau yaitu PT.Mitrametal Perkasa dimana aktivitasnya sebagai produsen otomotif bagi masyarakat industri otomotif terkait. Oleh karna itu penulis mengambil judul "Perencanaan Strategis Sistem Informasi Untuk Mendukung Mutu Dan Produktivitas Pada PT. Mitrametal Perkasa di Karawang”.

\section{Landasan Teori}

2.1 Perencanaan Strategis Sistem Informasi

Menurut Turban,E.R.(Turban, 2003:55) Perencanaan Strategis Sistem Informasi merupakan sekumpulan tujuan jangka panjang yang menggambarkan kebutuhan sistem yang arsitektur teknologi informasi untuk suatu perusahaan memiliki SI/TI, diantaranya :

1) Investasi pada SI/TI tidak mendukung sasaran bisnis.

2) Tidak terkontrolnya SI/TI yang ada

3) Sistem yang tidak terintegrasi, sehingga meyakinkan terjadinya duplikasi data dan hilangnya keterkaitan antar sumber daya informasi.

4) Perusahaan tidak mempunyai panduan untuk menentukan prioritas proyek SI/TI dan selalu terjadi perubahan sehingga menurunkan produktivitas.

5) Manajemen informasi yang buruk dan tidak akurat.

6) Strategi SI/TI tidak sejalan dengan strategi bisnis perusahaan.

7) Proyek SI/TI hanya dievaluasi pada bisnis keuangan semata.

Strategi SI/TI hendaknya dapat mengarahkan kinerja sistem secara terintegrasi untuk menghasilkan informasi yang dapat dijadikan sebagai masukan untuk pengambilan keputusan manajemen. 
Hubungan antara Strategis TI, Strategis SI dan Strategis bisnis, dapat kita lihat pada gambar di bawah ini :

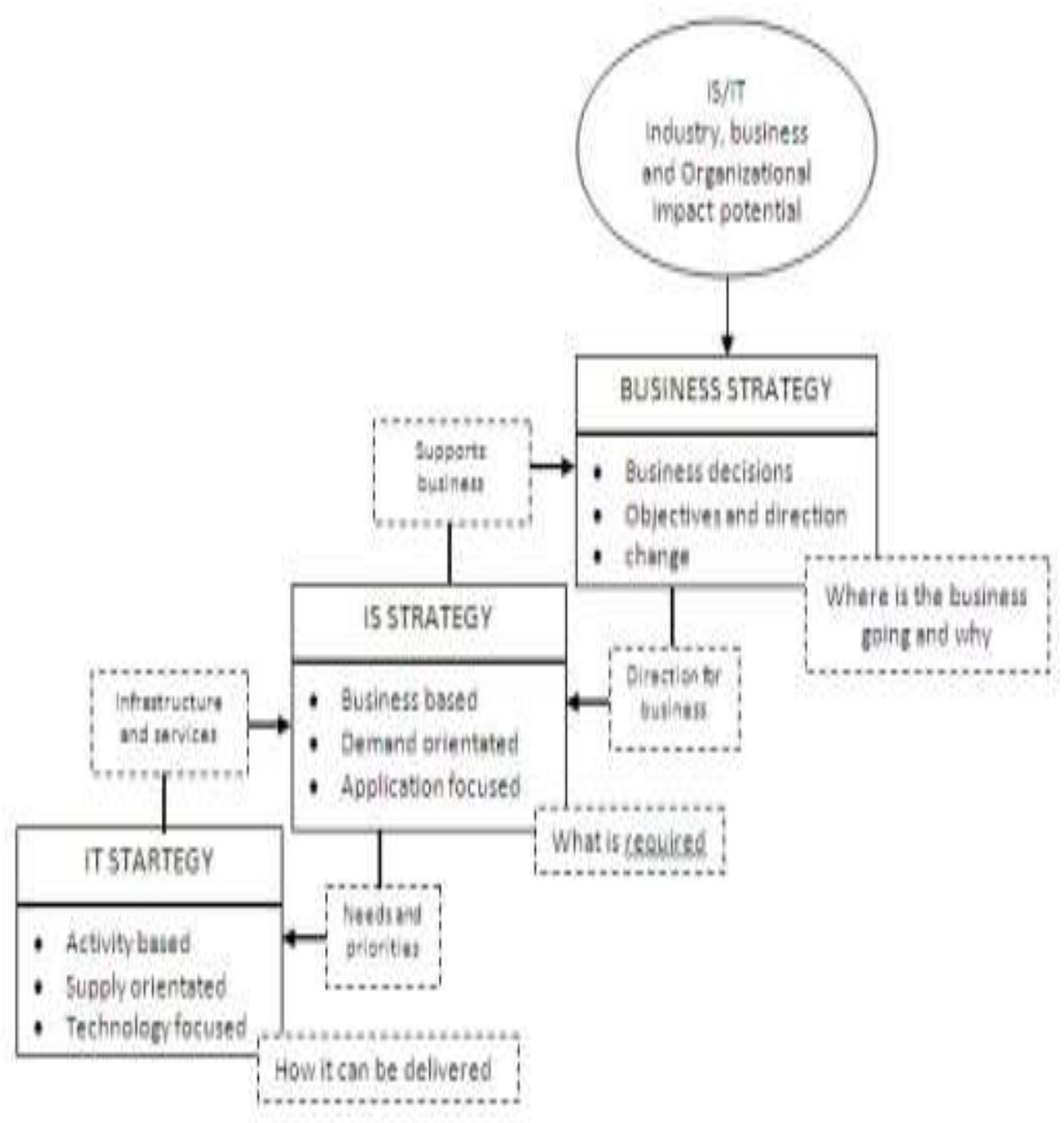

Gambar 2.1. Hubungan antara Strategis Bisnis, Strategis SI, Strategis TI [Ward \& Peppard 2002].

\subsection{Metodologi Perencanaan Strategis SI/TI}

Hal yang paling penting dalam suatu proses perencanaan strategis SI/TI adalah penggunaan metodologi. Metodologi merupakan kumpulan dari suatu metode, teknik dan tools untuk analisis yang digunakan dalam proses mengerjakan suatu kegiatan. Tujuan dari penggunaan metodologi dalam perencanaan strategis SI/TI adalah untuk meminimalkan ketergantungan terhadap individu dan lebih menekankan kepada proses dan sasaran yang ditentukan.

Pelaksanaan rencana strategis perusahaan, ada beberapa pilihan metodologi yang akan digunakan dari masing-masing metodologi mempunyai sebuah karakteristik metode yang berbeda dan memiliki pendekatan yang berbeda (langkah-langkah yang berbeda). Setiap metodologi mungkin menemukan satu atau lebih aspek-aspek tertentu sementara yang lain menekankan satu atau lebih aspek yang berbeda. Metodologi tertentu mungkin lebih cocok dalam satu perusahaan, bisa juga perusahaan tertentu yang mungkin memerlukan metodologi tersebut untuk digunakan. Maka dalam kaitannya dengan penyusunan tesis ini, metodologi yang akan digunakan menggunakan Versi Ward \& Peppard. 
3. Obyek Dan Metodologi Penelitian

3.1 Analisis Lingkungan Bisnis Internal Organisasi

1) Analisis $S W O T$

Tabel 4.2 Analisis Matriks SWOT

\begin{tabular}{|c|c|c|}
\hline \multirow[b]{2}{*}{ Opportunity $(\mathrm{O})$} & Strenghs (S) & Wealcuess (DV) \\
\hline & STRATEGI (SO) & STRATEGI (WO) \\
\hline 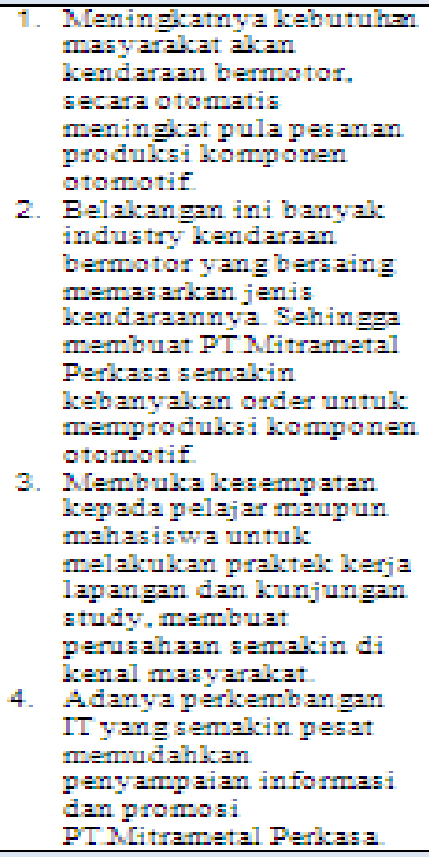 & 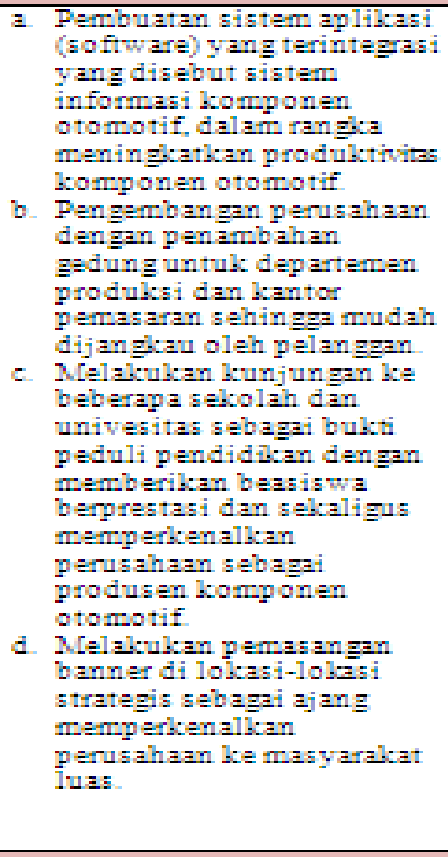 & 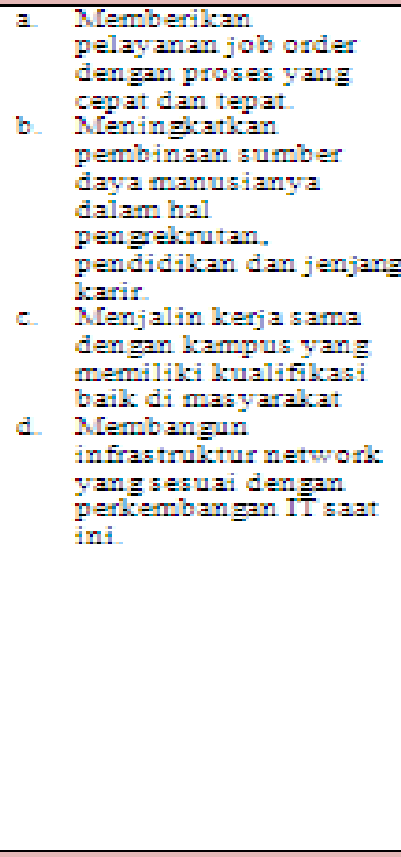 \\
\hline Threats (T) & STRATEGI (ST) & STRATEGI (NT) \\
\hline $\begin{array}{l}\text { 1. Adanya Kompetitor } \\
\text { industri sejenis maupun } \\
\text { tidak sejenis. } \\
\text { 2. Semalcin berkemban mya } \\
\text { teknologi informasi maka } \\
\text { hamu diimbangi dengan } \\
\text { kompetensi sumber daya } \\
\text { manusia (SDND yang } \\
\text { memiliki kemampuan } \\
\text { tersebut. }\end{array}$ & $\begin{array}{l}\text { a. Membuat sistem } \\
\text { pengendalian mutu guna } \\
\text { meninglcatkan keunggulan } \\
\text { kompetitif dari para } \\
\text { pesaing. } \\
\text { b. Meninglikan pelatihan } \\
\text { dan pendidikan untuk } \\
\text { memenuhi korpetensi } \\
\text { tersebut. }\end{array}$ & $\begin{array}{l}\text { a. Meningicatkan } \\
\text { penbinaan SDM dalan } \\
\text { hal pengrekrutan. } \\
\text { pendidikan dan jenjang } \\
\text { karir, terutama dalar. } \\
\text { bidang SI TI. } \\
\text { b. Menyiaplian SI guna } \\
\text { meningicatian proses } \\
\text { bisnis perusahaan }\end{array}$ \\
\hline
\end{tabular}

2) Anali

Aktifitas utama dan aktifitas pendukung pada PT.Mitrametal Perkasa dengan menggunakan analisis value chain ini dapat dilihat pada gambar 4.1 berikut ini :

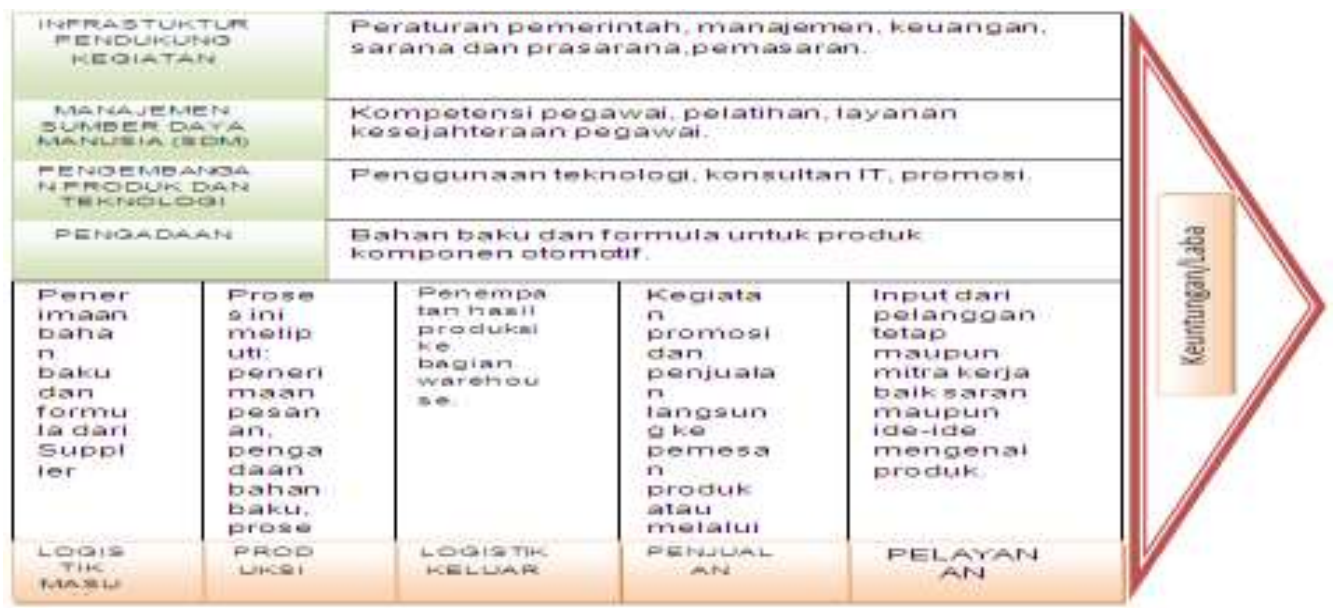


3) Analisis Porter's Five Force pada PT.Mitrametal Perkasa Analisis Five Force Competitive dapat dilihat pada gambar 4.2 berikut.

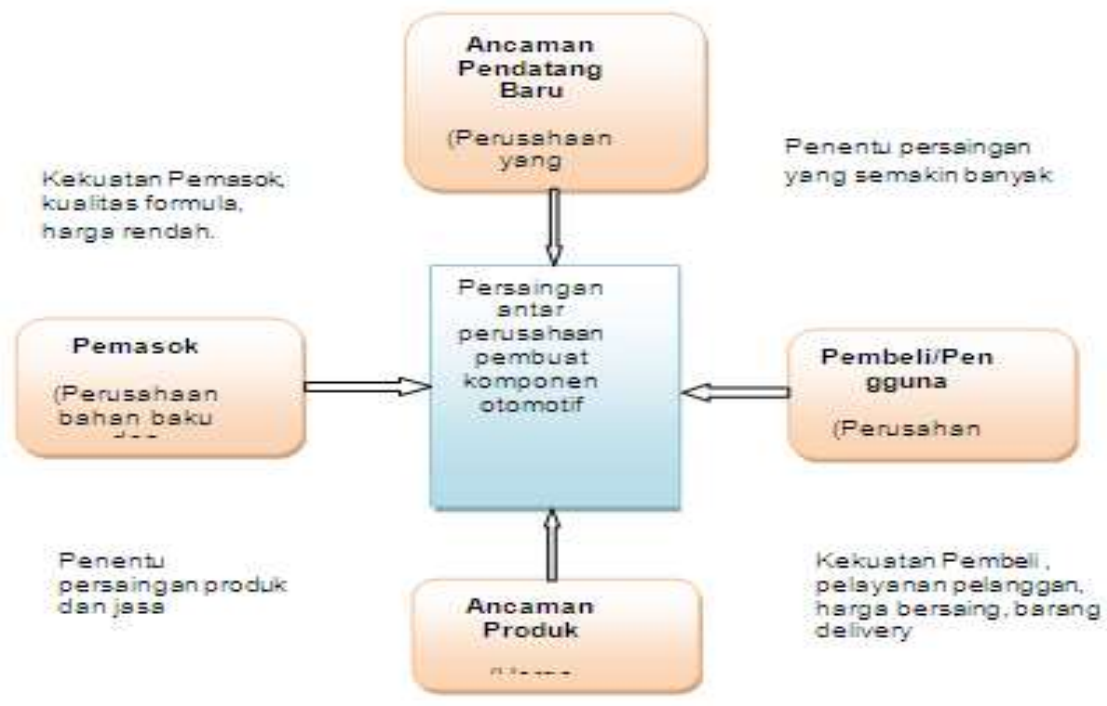

Gambar 4.2 Pemetaan hasil Analisis Five Force Competitive Model

4) Analisis BSC (Balance Score Card) pada PT.Mitrametal Perkasa

Balanced Scorecard digunakan pada tingkat organisasi enterprise.

\begin{tabular}{|c|c|c|c|c|}
\hline No & $\begin{array}{c}\text { Tujuan Utama } \\
\text { PT Mitrametal } \\
\text { Perkasa }\end{array}$ & $\begin{array}{c}\text { Kriteria Sukses } \\
\text { (Measure) }\end{array}$ & $\begin{array}{l}\text { Faktor Kunci } \\
\text { Keberhasilan } \\
\text { (CSF) }\end{array}$ & $\begin{array}{l}\text { Kebutuhan } \\
\text { Informasi }\end{array}$ \\
\hline \multirow[t]{4}{*}{1} & \multirow[t]{4}{*}{$\begin{array}{l}\text { Meningkatkan } \\
\text { kapasitas produksi }\end{array}$} & \multirow{4}{*}{$\begin{array}{l}\text { Adanya } \\
\text { peningkatan } \\
\text { produksi } \\
\text { komponen } \\
\text { otomotif } \\
\text { PT.Mitrametal } \\
\text { Perkasa }\end{array}$} & $\begin{array}{l}\text { Penambahan } \\
\text { perangkat produksi } \\
\text { komponen otomotif }\end{array}$ & $\begin{array}{l}\text { Data sarana dan } \\
\text { prasarana di } \\
\text { divisi produksi }\end{array}$ \\
\hline & & & $\begin{array}{l}\text { Penambahan } \\
\text { pegawai untuk } \\
\text { divisi produksi }\end{array}$ & Data pegawai \\
\hline & & & $\begin{array}{l}\text { Penambahan dana } \\
\text { operasional } \\
\text { produksi }\end{array}$ & $\begin{array}{l}\text { Data keuangan } \\
\text { operasional }\end{array}$ \\
\hline & & & $\begin{array}{l}\text { Penambahan hasil } \\
\text { produksi komponen } \\
\text { otomotif }\end{array}$ & $\begin{array}{l}\text { Data keuangan } \\
\text { penjualan } \\
\text { produk }\end{array}$ \\
\hline 2 & $\begin{array}{l}\text { Mendatangkan } \\
\text { pelanggan tetap } \\
\text { yangloyal }\end{array}$ & $\begin{array}{l}\text { Adanya } \\
\text { penambahan } \\
\text { pelanggan dari } \\
\text { sistem layanan } \\
\text { informasi }\end{array}$ & $\begin{array}{l}\text { Meningkatkan } \\
\text { kepuasan } \\
\text { pelanggan dengan } \\
\text { cara sistem } \\
\text { AutoOrder }\end{array}$ & $\begin{array}{l}\text { Data pelanggan } \\
\text { baru }\end{array}$ \\
\hline 3 & $\begin{array}{l}\text { Menjadiprodusen } \\
\text { otomotif terbaik di } \\
\text { Indonesia }\end{array}$ & $\begin{array}{l}\text { Adanya } \\
\text { pengakuan } \\
\text { khusus mengenai } \\
\text { produk dari } \\
\text { pelanggan atau } \\
\text { pemerintah } \\
\text { terhadap } \\
\text { PT.Mitrametal } \\
\text { Perkasa }\end{array}$ & $\begin{array}{l}\text { Peningkatan proses } \\
\text { produksi komponen } \\
\text { otomotif }\end{array}$ & $\begin{array}{l}\text { Data keuangan } \\
\text { penjualan } \\
\text { produk }\end{array}$ \\
\hline
\end{tabular}


5) Strategis Layanan PT.Mitrametal Perkasa dalam Balanced Scorecard

PT.Mitrametal Perkasa dalam kerangka Balanced Scorecard yaitu pada gambar 4.3.

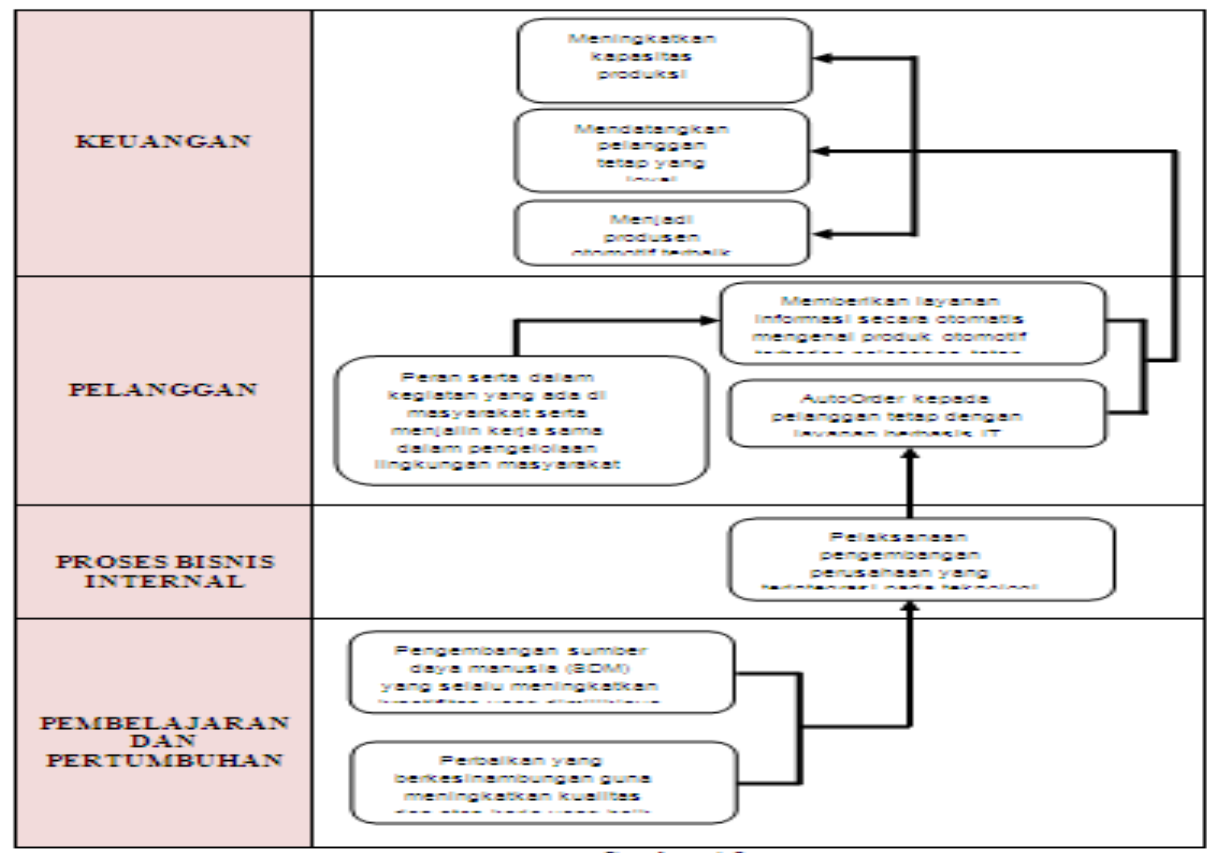

Gambar 4.3

Strategis Map PT.Mitrametal Perkasa

3.2 Analisis Lingkungan Internal SI/TI Organisasi

Pada sub tahapan ini yaitu mencakup analisis seluruh sumber daya SI yaitu sistem aplikasi yang telah ada dan dimanfaatkan oleh PT.Mitrametal Perkasa untuk keperluan bisnisnya, yaitu :

1) Website PT.Mitrametal Perkasa.

Web ini berisi informasi mengenai profile dan produk yang ada di perusahaan saja, namun penyajian informasinya masih belum lengkap menggambarkan tentang profile PT.Mitrametal Perkasa beserta layanan yang khusus kepada pelanggan.

2) Program Aplikasi Transaksi Pembayaran dan Penjualan.

Program aplikasi ini menangani sistem pembayaran pegawai, bahan baku produk dan penjualan produk komponen otomotif. Namun masih memiliki kelemahan yaitu belum terintegrasinya data-data pegawai dan penyediaan barang/material.

3.3 Analisis Lingkungan Eksternal SI/TI Organisasi

1) Perkembangan Teknologi.

Perkembangan dunia E-Commerce dan jaringan Mobile menjadi pendorong bagi PT.Mitrametal untuk menggunakan teknologi dalam kegiatan operasional proses bisnis dan untuk meningkatkan layanan kepada pelanggan yang bisa diakses setiap saat tanpa terbatas oleh ruang dan waktu.

2) Peluang Keunggulan Kompetitif terhadap Pesaing.

Melalui penggunaan teknologi yang dimanfaatkan disetiap kegiatan operasional proses bisnis, akan menetapkan PT.Mitrametal menjadi perusahaan produsen otomotif terbaik dan terdepan dalam menerapkan penggunaan E-Commerce dan jaringan Mobile dalam kegiatan operasional proses bisnis dan layanan kepada pelanggannya, sehingga memiliki nilai keunggulan kompetensi yang tinggi.

\section{Tahapan Keluaran : Menentukan Strategi SI/TI}

4.1 Strategi Bisnis SI

1) Identifikasi Masalah dan Solusi Bisnis Internal

Permasalahan yang masih sering terjadi khususnya berhubungan dengan SI/TI adalah :

a) Belum mendukungnya keahlian sumber daya manusia dalam bidang SI/TI

b) Dalam melakukan back-up data-data perusahaan belum terkoordinir dengan baik

c) Untuk laporan baik harian, mingguan, maupun bulanan di setiap divisi seringkali mengalami keterlambatan

d) Penyimpanan data-data di setiap divisi masih belum terpusat 
Adapun solusi yang dapat diberikan yaitu :

a) Memberikan pelatihan (training) yang komprehensif kepada pegawai, khususnya di bagian adm, staf dan staf IT.

b) Data perusahaan disetiap divisi yang telah diBackup, harus selalu disimpan sesuai urutan masternya dan apabila diperlukan bisa dibagikan ke divisi sesuai urutan kebutuhan

c) Adanya pemasangan sistem jaringan dan menggunakan sharing data yang langsung terpusat sehingga laporan dari setiap divisi tidak mengalami keterlambatan.

d) Harus ada devisi IT yang khusus menangani masalah teknologi informasi di perusahan.

2) Identifikasi peluang bisnis dari Eksternal Organisasi

Identifikasi peluang yang memanfaatkan SI pada :

a) Konsumen yaitu proses bisnis dapat diselesaikan dengan cepat sehingga meningkatkan layanan dan kepuasan pelanggan yang ingin produk komponen otomotifnya di produksi oleh PT.Mitrametal.

b) Pesaing yaitu dengan menggunakan SI yang handal dan tepat sasaran maka PT.Mitrametal dapat bersaing dari pesaing-pesaing yang ada di Indonesia.

c) Investor yaitu menarik para investor untuk berinvestasi di PT.Mitrametal karena memiliki kualitas dan produktivitas yang baik.

3) Identifikasi Pemanfaatan SI/TI dari Lingkungan Eksternal Organisasi Identifikasi pemanfaatan SI/TI pada PT.Mitrametal Perkasa yaitu :

a) Meningkatkan jumlah pelanggan yang akan memproduksi komponen otomotif di PT.Mitrametal.

b) Sebagai perusahaan produsen komponen otomotif yang memiliki karakter atau citra baik di masyarakat.

c) Meningkatkan jumlah investor untuk berinvestasi di PT.Mitrametal Perkasa.

4) Analisis usulan Portofolio Strategi SI

Analisis usulan portofolio Strategi SI PT.Mitrametal ditentukan berdasarkan identifikasi CSF yang bertujuan menganalisis kebutuhan informasi pada PT.Mitrametal untuk dicarikan pemenuhannya. Tabel dibawah ini merupakan penjelasan dari usulan tersebut. Tabel 4.7 Analisis Usulan Portofolio SI.

\begin{tabular}{|c|c|c|c|c|}
\hline$x=$ & $\begin{array}{l}\text { IT } \\
\text { TI }\end{array}$ & 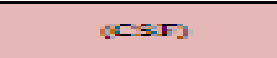 & 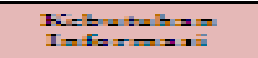 & 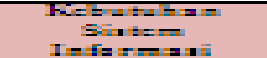 \\
\hline 7 & 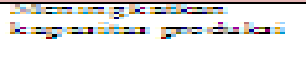 & 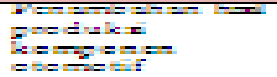 & 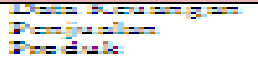 & 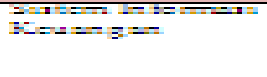 \\
\hline$=$ & 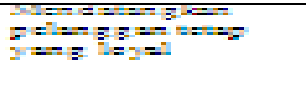 & 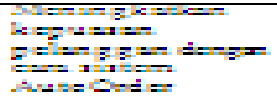 & 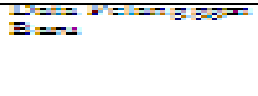 & 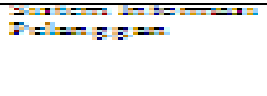 \\
\hline$=$ & 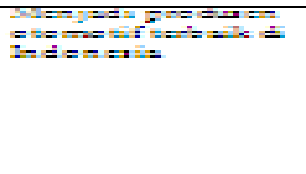 & 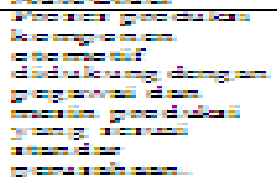 & 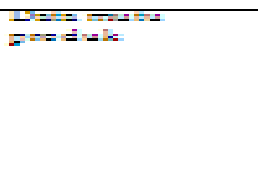 & $y=z-1=0=0$ \\
\hline$=$ & 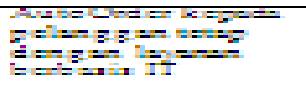 & 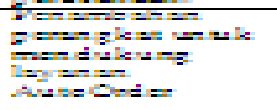 & 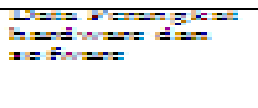 & $7=-1=19=1$ \\
\hline$=$ & 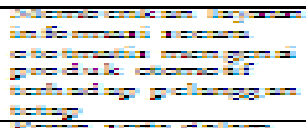 & 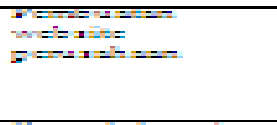 & 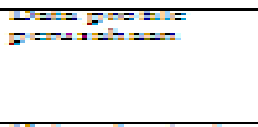 & 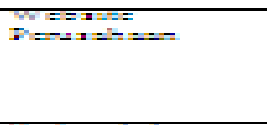 \\
\hline & 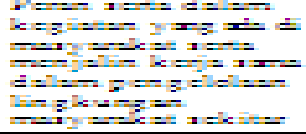 & 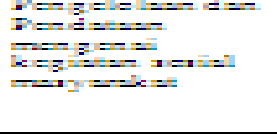 & $g=-1=$ & Ban \\
\hline & 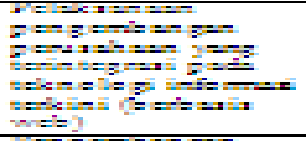 & 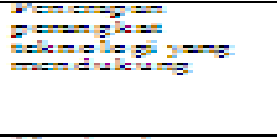 & 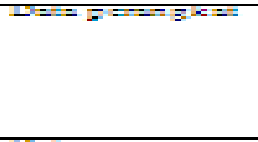 & 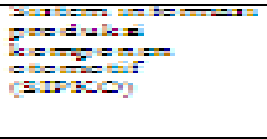 \\
\hline$=$ & 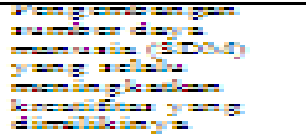 & 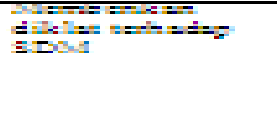 & 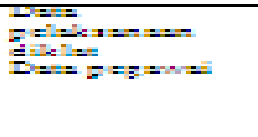 & 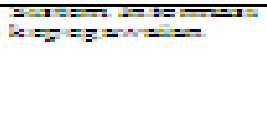 \\
\hline$=$ & 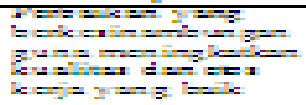 & 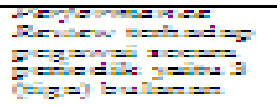 & 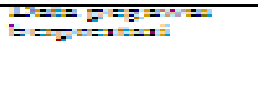 & \\
\hline
\end{tabular}




\subsection{Strategi TI}

1) Membuat Landasan Kebijakan SI/TI

Misi SI/TI PT.Mitrametal pertumbuhan industry otomotif yang harus dilaksanakan untuk mewujudkan visi adalah sebagai berikut :

a) Penyediaan SI/TI yang dapat meningkatkan produktivitas prusahaan

b) Penyediaan SI/TI yang mampu meningkatkan kualitas produk perusahaan

c) Pengelolaan sumber daya SI/TI secara efektif dan efesien sehingga dapat menjadikan PT.Mitrametal Perkasa sebagai perusahaan terbaik di Indonesia untuk produsen komponen otomotif

d) Penyediaan SI/TI yang dapat memenuhi kebutuhan informasi bagi pimpinan untuk pengambilan keputusan yang lebih tepat

e) Peningkatan kualitas SDM dalam penguasaan SI/TI terkini

2) Membuat Strategi SI/TI

a) Website PT.Mitrametal Perkasa

Untuk website perusahaan sudah ada, namun masih belum maksimal performanya sehingga websitenya masih belum dinamis . Untuk itu dibutuhkan perancangan website yang didukung oleh software yang khusus dalam pembuatan website serta database yang mendukung untuk mengelola data-data perusahaan dan dapat pula mengakomodir seluruh informasi tentang perusahaan, agar lebih dikenal luas oleh masyarakat.

b) Sistem Informasi Produksi Komponen Otomotif (SIPKO)

Dengan dibuatnya sistem SIPKO diharapkan dapat meminimalisir resiko terjadinya kesalahan dalam proses pemesanan, penerimaan dan pengiriman. Sehingga kegiatan proses produksi bisa dilakukan dengan efektif dan efisien.

c) Sistem Informasi Penjualan Produk

Sistem penjualan produk yang akan direncanakan adalah melalui media internet berbasis website, yang memungkinkan pelanggan melakukan Job Order dimana saja, tanpa ada batasan waktu kerja, dan cepat dengan layanan AutoOrder.

d) Sistem Informasi keuangan

Program Aplikasi ini digunakan untuk memberikan kemudahan kepada manajemen perusahaan dalam melakukan kegiatan penggajian karyawan, pengelolaan Bonus, perhitungan income perusahaan dan kegiatan yang mencakup seluruh perputaran uang masuk dan keluar.

e) Sistem Informasi Kepegawaian

Program Aplikasi ini digunakan untuk memberikan kemudahan kepada melakukan pengelolaan absensi karyawan, pindah bagian,promosi jabatan dan teguran. Dengan adanya sistem ini diharapkan manajemen dapat dengan cepat mendapatkan informasi tentang kepegawaian, dan memonitoring kinerja karyawan, sehingga akan terjadi tertib administrasi, tertib dokumentasi perusahaan.

f) Sistem Informasi Pengendali Mutu (SIPM)

Sistem informasi ini digunakan untuk memberikan kemudahan kepada pengelola produk dalam melakukan kendali standar mutu, evaluasi, pendokumentasian data, pengembangan pelayanan, menghindari terulangnya kesalahan. Dengan adanya sistem informasi ini diharapkan informasi yang dibutuhkan mengenai nilai-nilai mutu produk komponen otomotif bisa dihasilkan setiap saat secara tepat dan akurat.

g) Sistem Informasi Pelanggan

Program Aplikasi ini digunakan untuk kebutuhan pelayanan pelanggan, dengan adanya sistem ini diharapkan manajemen dapat dengan cepat mendapatkan informasi tentang data pelanggan, pelanggan yang masuk dan lain sebagainya.

h) Sistem Informasi Kemitraa

Program aplikasi ini dipergunakan untuk pelayanan terhadap relasi atau mitra perusahaan yang sudah menjalin kerjasama agar tetap terjalin hubungan yang baik dan mengetahui produk-produk perusahaan. 
3) Strategi Manajemen SI/TI

Mengontrol keadaan SI/TI perusahaan setiap saat. Usulan struktur organisasi yang baru dapat dilihat pada gambar dibawah ini :

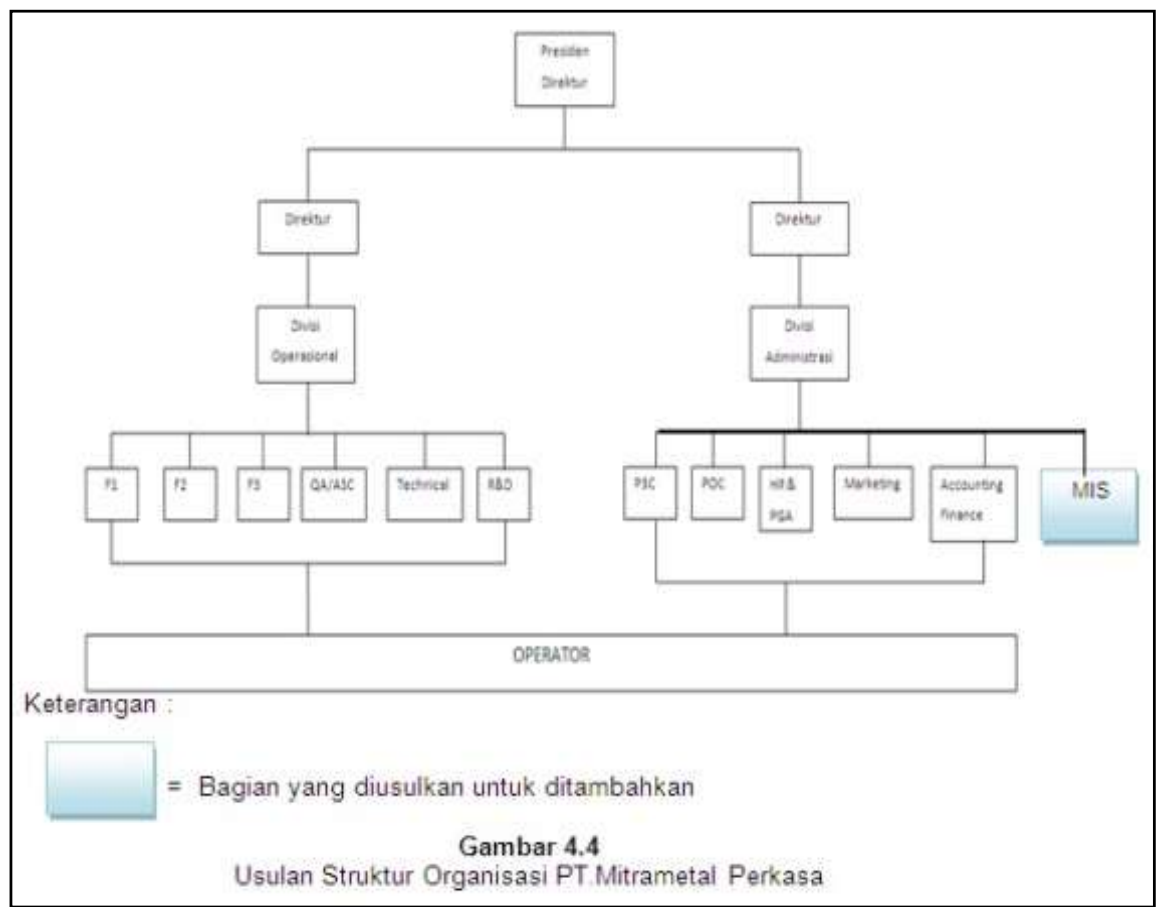

4) Infrastruktur Sistem Informasi

a) Merancang infrastruktur usulan Internet berbasis web untuk layanan informasi perusahaan sesuai dengan visi dan misi serta tujuan perusahaan sesuai dengan perkembangan teknologi saat ini dan masa yang akan datang.

b) Merancang infrastruktur usulan jaringan internet berbasis web untuk mengintegrasikan data dari masing-masing devisi perusahaan untuk menunjang efektif dan efisiensi proses bisnis sesuai dengan kebutuhan SI/TI pada masa yang akan datang.

c) Membuat area Hotspot di ruang istrirahat karyawan dan lobi front office, sehingga karyawan dapat melepas lelah, setelah bekerja, dan pelanggan dan tamu yang akan berkunjung bisa browsing sambil menunggu. Ini merupakan nilai plus bagi perusahaan.

5) Arahan atau Penjabaran dari Strategis SI/TI

Penjabaran Strategis yang diusulkan untuk PT.Mitrametal Perkasa adalah sebagai berikut:

a) Untuk hal Informasi perusahaan dapat disebarkan melalui internet berbasis website sehingga semua masyarakat dapat mengakses informasi mengenai perusahaan dimanapun berada. terutama khususnya untuk kota karawang. Kegiatan Job Order dapat dilakukan melalui Sistem Informasi berbasis Website PT.Mitrametal Perkasa yang dapat dilakukan dimanapun tanpa harus melalui telepon dan fax maupun datang langsung ke perusahaan.

b) Dalam melaksanakan pengembangan sistem Informasi, sehingga semua alur manajemen perusahaan dapat terkontrol, terintegrasi, update informasi sehingga memudahkan seluruh pihak perusahaan dan pelanggan dalam mendapatkan informasi yang diinginkan.

c) Membuat Sistem Informasi Kepegawaian yang mengakomodir semua pengelolaan kepegawaian,diantaranya mengenai, absensi karyawan, promosi, mutasi antar devisi, shift karyawan, reward karyawan, ulang tahun karyawan dan surat peringatan karyawan.

d) Membuat Sistem Informasi Keuangan yang mengakomodir semua pengelolaan keuangan ,diantaranya mengenai, penggajian karyawan, pemberian bonus, income perusahaan, arus perputaran pendapatan dan pengeluaran keuangan perusahaan. 
6) Aplikasi Portofolio SI/TI mendatang

Analisis portofolio juga dapat dianggap sebagai penetapan prioritas kebutuhan sistem informasi dalam kaitannya dengan investasi. Dibawah ini adalah tabel Aplikasi portofolio, perencanaan strategis SI/TI dan strategis bisnis PT.Mitrametal Perkasa untuk 3 (Tiga) tahun mendatang sebagai berikut:

Tabel 4.8 Aplikasi Portofolio SI/TI PT.Mitrametal Perkasa

\begin{tabular}{|l|l|}
\hline \multicolumn{1}{|c|}{ STRATEGIS } & HIGH POTENTIAL \\
\hline $\begin{array}{l}\text { 1. Membangun Sistem Informasi Keuangan } \\
\text { 2. Membangun Sistem Informa si Pelanggan }\end{array}$ & 1. Sistem Informasi Kepegawaian \\
\hline $\begin{array}{l}\text { 1. Website PT.Mitrametal Perkasa } \\
\text { 2. Stomotif(SIPKO) } \\
\text { 3. Sistem Informasi Penjualan Produk }\end{array}$ & $\begin{array}{l}\text { 1. Sistem Informasi Pengendali Mutu } \\
\text { (SIPM) } \\
\text { Sistem Informasi Kemitraan }\end{array}$ \\
\hline KEY OPERATIONAL & SUPPORT \\
\hline
\end{tabular}

7) Tahapan Akhir : Rencana Implementasi

Pada tahap akhir ini akan menghasilkan dokumen akhir berupa rencana dan jadwal implementasi solusi strategi SI/TI. Rencana dan jadwal kerja implementasi strategis SI/TI dapat dilihat pada tabel di bawah ini :

Tabel 4.9 Rencana dan jadwal kerja implementasi strategis SI/TI

\begin{tabular}{|c|c|c|c|c|c|c|c|c|c|c|c|c|c|c|c|c|c|c|c|c|c|c|c|c|c|c|c|c|}
\hline \multirow{4}{*}{ No } & \multirow{4}{*}{$\begin{array}{l}\text { NAMA } \\
\text { PROYEK }\end{array}$} & \multicolumn{27}{|c|}{ Jadwal Kerja Proyek } \\
\hline & & \multirow{2}{*}{\multicolumn{12}{|c|}{$\begin{array}{l}\text { Tahun } 2014 \\
\text { November }\end{array}$}} & \multirow{2}{*}{\multicolumn{15}{|c|}{\begin{tabular}{c}
\multicolumn{2}{c|}{ Tahun 2015} \\
Februari
\end{tabular}}} \\
\hline & & & & & & & & & & & & Desember & & & & & & & & & & & & & & & & \\
\hline & & 1 & \multicolumn{3}{|c|}{ Oktober } & \begin{tabular}{l|l}
1 & \\
\end{tabular} & \begin{tabular}{|l|l|}
2 & 3 \\
\end{tabular} & $4 \mid$ & 5 & 1 & \begin{tabular}{|l|l}
23 \\
3
\end{tabular} & \begin{tabular}{|l|}
4 \\
\end{tabular} & 5 & 1 & \begin{tabular}{l|l}
2 & 3 \\
2
\end{tabular} & \begin{tabular}{|l|}
4 \\
\end{tabular} & 5 & 1 & \begin{tabular}{|l|l|}
2 & 3 \\
\end{tabular} & & 5 & 1 & \begin{tabular}{l|l}
2 & 3 \\
\end{tabular} & 4 & 5 & 1 & \begin{tabular}{l|l}
2 & 3 \\
\end{tabular} & \begin{tabular}{|l|l|}
4 & 5 \\
\end{tabular} \\
\hline 1 & $\begin{array}{l}\text { Perancangan } \\
\text { dan } \\
\text { pembuatan } \\
\text { jaringan } \\
\text { komputer }\end{array}$ & & & & & & & & & & & & & & & & & & & & & & & & & & & \\
\hline 2 & $\begin{array}{l}\text { Pembuatan } \\
\text { website } \\
\text { perusahaan }\end{array}$ & & & & & & & & & & & & & & & & & & & & & & & & & & & \\
\hline 3 & \begin{tabular}{|l|} 
Sistem \\
Informasi \\
Keuangan
\end{tabular} & & & & & & & & & & & & & & & & & & & & & & & & & & & \\
\hline 4 & \begin{tabular}{|l|} 
Sistem \\
informasi \\
penjualan \\
produk \\
berbasis web
\end{tabular} & & & & & & & & & & & & & & & & & & & & & & & & & & & \\
\hline 5 & $\begin{array}{l}\text { Sistem } \\
\text { informasi } \\
\text { (SIPKO) }\end{array}$ & & & & & & & & & & & & & & & & & & & & & & & & & & & \\
\hline 6 & $\begin{array}{l}\text { Sistem } \\
\text { informasi } \\
\text { (SIPM) }\end{array}$ & & & & & & & & & & & & & & & & & & & & & & & & & & & \\
\hline 7 & \begin{tabular}{|l|} 
Sistem \\
informasi \\
pelanggan
\end{tabular} & & & & & & & & & & & & & & & & & & & & & & & & & & & \\
\hline 8 & \begin{tabular}{|l|} 
Sistem \\
informasi \\
kepegawaian
\end{tabular} & & & & & & & & & & & & & & & & & & & & & & & & & & & \\
\hline 9 & $\begin{array}{l}\text { Sistem } \\
\text { informasi } \\
\text { kemitraan }\end{array}$ & & & & & & & & & & & & & & & & & & & & & & & & & & & \\
\hline
\end{tabular}




\section{Kesimpulan}

Berdasarkan uraian dan pembahasan yang telah dilakukan pada bab-bab sebelumnya, maka kesimpulan yang diperoleh dari penelitian ini adalah sebagai berikut:

1. Pemanfaatan sistem dan teknologi Informasi di PT.Mitrametal Perkasa masih belum di implementasikan seluruhnya dan tidak terintegrasi satu sama lainnya. Hal ini terlihat dari belum adanya dokumen perencanaan strategis sistem dan teknologi informasi yang dapat digunakan sebagai acuan bagi seluruh unit kerja sehingga saat ini pemanfaatan SI/TI belum mencapai hasil yang maksimal.

2. Dalam penelitian ini menggunakan metodologi Ward and Peppard yang terdiri tahapan masukan yaitu Analisis lingkungan bisnis internal, Analisis lingkungan bisnis eksternal, Analisis lingkungan SI/TI internal, dan Analisis lingkungan SI/TI eksternal. Sedangkan untuk tahapan keluaran yaitu Strategi SI Bisnis, Strategi TI, dan Strategi Managemen SI/TI. Dengan analisis strategis menggunakan analisis Value Chain, PEST, dan SWOT. Hasil yang dicapai yaitu membuat suatu kerangka kerja perencanaan strategi SI/TI yang terintegrasi yang meliputi area organisasi, infrastruktur teknologi dan aplikasi sehingga memudahkan manajemen mengelola sumber daya untuk menghasilkan informasi yang dibutuhkan, akurat dan dapat digunakan oleh semua pihak.

3. Perencanaan Strategis Sistem dan Teknologi Informasi yang sudah dibahas dapat menjadikan PT.Mitrametal Perkasa memiliki keunggulan kompetitif dalam menghadapi persaingan dengan Perusahaan sejenis dan meningkatkan daya saing yang meningkatkan kompetensi perusahaan dan kompetensi pegawai sehingga tujuan perusahaan tercapai.

4. Dengan adanya Perencanaan Strategis Sistem dan Teknologi Informasi pada PT.Mitrametal Perkasa, maka struktur organisasi perlu ditambahkan satu divisi yaitu divisi MIS, hal tersebut agar perencanaan strategis dapat dilaksanakan dengan cepat dan berkesinambungan.

5. Berdasarkan hasil analisis, maka didapatkan portofolio aplikasi SI PT.Mitrametal Perkasa yaitu : Sistem Informasi Keuangan, Sistem Informasi Pelanggan, Sistem Informasi (SIPKO), Sistem Informasi Kepegawaian, Sistem Informasi Kemitraan, Sistem Informasi (SIPM) dan Website PT.Mitrametal Perkasa.

\section{DAFTAR PUSTAKA}

Grant, R.M. (2002), Strategic management, cetakan ke-3. Jakarta: PT.Elex Media Komputindo.

Grembergen V., W., Saull, R., and De Haes, S. Linking the IT Balanced Scorecard to the Business Objectives at a Major Canadian Financial Group. Journal of Information Technology Cases and Application, Vol. 5, No. 1. 2003.

Hartono B., Sistem Informasi Manajemen Berbasis Komputer, Rineka Cipta, Jakarta 2013.

Hasibuan, Z. 2007. Model Perencanaan Strategis System Informasi pada Industri Televisi dengan Pendekatan Blue Ocean dan Balanced Scorecard. Jurnal Ilmiah (diunduh tanggal 16 maret 2014).

Indrajit, R. E. (2002). Pengantar Konsep Dasar : Manajemen Sistem Informasi dan Teknologi Informasi, Cetakan ke-2. Jakarta : PT.Elex Media Komputindo.

Kaye J., Perancangan Strategis Bagi Organisasi Nirlaba: Pedoman Praktis Buku Kerja/ Michael Allison. Ed.1 , Yayasan Pustaka Obor Indonesia, Jakarta 2014.

Rangkuti. F., Analisa SWOT Teknik membedah kasus bisnis: Reorientasi Konsep Perencanaan Strategis untuk Menghadapi Abad 21, 14 $4^{\text {th }}$ ED, Gramedia Pustaka Utama, Jakarta 2013.

Rangkuti. F., SWOT BALANCED SCORECARD Teknik Menyusun Strategi Korporat yang Efektif plus Cara Mengelola Kinerja dan Risiko, Gramedia Pustaka Utama, Jakarta 2013.

Ward, J., Peppard, J., Strategic Planning For Information Systems, John Wiley \& Son, West Sussex, 2003.

Wedhasmara A., Langkah-langkah Perencanaan Strategis Sistem Informasi Dengan Menggunakan Metode Ward and Peppard, Fasilkom UNSRI, Vol 1/No.1/April 2009.

Wijaya Andri, S. d. 2011. Perencanaan Strategis Sistem Informasi dan Teknologi Informasi pada perusahaan Otomotif dengan menggunakan metodologi TOZER. SNATI. 